\title{
Rhazes' Contributions to Alchemy and Pharmacy
}

\author{
Ensiye Affi ${ }^{1,2}$, Samaneh Soleymani (iD) ${ }^{1,}$ and Arman Zargaran (iD) ${ }^{1,3}$ \\ ${ }^{1}$ Department of Traditional Pharmacy, School of Persian Medicine, Tehran University of Medical Sciences, Tehran, Iran \\ ${ }^{2}$ Student Scientific Research Center (SSRC), Tehran University of Medical Sciences, Tehran, Iran \\ ${ }^{3}$ Department of History of Medicine, School of Persian Medicine, Tehran University of Medical Sciences, Tehran, Iran \\ "Corresponding author: Department of Traditional Pharmacy, School of Persian Medicine, Tehran University of Medical Sciences, Tehran, Iran Email: \\ s.soleymani84@gmail.com
}

Received 2020 November 23; Revised 2021 April 21; Accepted 2021 August 29.

\begin{abstract}
Context: Persia has been the cradle of science across human history. Many of today's concepts in science, such as the finite speed of light and alcohol distillation, were first proposed by Persian scientists. Mohammad ibn Zakariya Razi (Rhazes) is undoubtedly one of the greatest Persian scientists over human history.

Evidence Acquisition: In this paper, in addition to a brief review of the history of pharmacy and chemistry sciences in Persia, Rhazes' valuable books in the fields of pharmacy and chemistry, along with a brief description of them, were introduced. Data were extracted from different historical and bibliography books and also the citation databases of PubMed, Scopus, and Google Scholar. Results: Rhazes' books and treatises in the fields of pharmacy and chemistry have been classified into three categories:1) the books and treatises containing some sections on pharmacy like Al-Hawi fi al-Tibb (Liber Continens) and Al-Mansouri fi al-Tibb, 2) those written merely on pharmacy, like Qarabadin (pharmacopeia), and 3) the books focusing on alchemy (kimia), like Sirr al-Asrar (Secret of secrets) and Al Asrar (Liber Secretorum). Three volumes of Al Hawi fi al-Tibb were applied as a reference in pharmacology in Western universities for many years. Sirr al-Asrar is his most important book on alchemy, describing raw materials used in alchemy, experimental apparatus necessary for alchemical investigations, and detailed procedures for the chemical manipulation of arsenic and sulfur.

Conclusions: These valuable manuscripts demonstrate the ancient heritage of Persians and the great roles and contributions of Persian scientists in the history of science.
\end{abstract}

Keywords: Rhazes, History of Pharmacy, Chemistry, Iran, History of Alchemy

\section{Context}

According to the great American historian of pharmacy, George A. Bender, pharmacy is defined as "a scientific profession and the art of providing, protecting, combining, and dispensing medications, which has a unique record of service provision to humanity approximately as old as the human generation" (1). The origin of the word "pharmacy" dates back to the ancient Egyptian mythology, Thoth, the scribe among the gods known as ph-ar-imki, which means the warrant of security (2). The Graeco-Latin pharmakon means drug, either remedy or poison (3). Pharmacists, as persons who would prepare and administer remedies to patients, have been known under terms such as shamans, apothecaries, healers, priests, physicians, diviners, chemists, druggists, and pharmaceutists, as well as others over time (4). Prehistoric people engraved drawings of plants on deer antlers and bones, perhaps as a way to pass their knowledge of the environment to their poster- ity as early as 80,000 years ago (3). Early communities soon progressed in knowledge about edible plants and their importance for body growth, as well as poisonous herbs that were effective in mitigating symptoms of diseases via trial, error, and careful observation. Also, animal and mineral products were applied in early folk medicine (5).

Alchemy was not just a collection of chemical instructions for converting metals or combining them together via chemical bonds, but it was one of the most important branches of natural philosophy delving into universe creation (6). The parallel use of the two words of 'alchemy' and 'chemistry' by writers in the 17th century, such as Nicolas Lemery, has created considerable confusion among science historians (7). According to a comprehensive study by Newman et al., the assumption that chemistry and alchemy indicated separate disciplines before the 17th century was misleading, and efforts to separate them are useless (7). Both pharmacy and alchemy have a deep history and were applied as two close majors during civilization, 
and in fact, they were developed in many civilizations, including Persia.

Persia was a cradle of different sciences in ancient times and medieval ages. Also, Persia at the beginning of ancient times was the center of scientific achievements and the conduit of knowledge from India and China in the East to Rome and Greece in the West. Persian scientists were active in progressing sciences and technologies such as alchemy, mathematics, architecture, astronomy, biology, anatomy, botany, cosmology, engineering, medicine, and pharmacy (8). Many of today's concepts in science, such as wind-power machine, finite speed of light, gravity, alcohol distillation, Helio-Centric model of the solar system, etc., were first proposed by Persian scholars. In the realm of the Sassanid dynasty, Persia was home to the earliest libraries and universities in the world (8). Rhazes is undoubtedly one of the greatest Persian scientists, physicians, pharmacists, and alchemists in human history. In this paper, in addition to a brief review on the history of pharmacy and chemistry in Persia, Rhazes' valuable books in the fields of pharmacy and chemistry, along with a brief description of them, are introduced.

\section{Evidence Acquisition}

Data were extracted from different historical and bibliography books such as "Moallefat va Mossanafat Razi", the manuscripts written by Mohammad Najmabadi, the "Making medicines" book written by Stuart Anderson, etc. Also, in the next phase of this study, the literature was searched in the citation databases of PubMed, Scopus, and Google Scholar.

\section{Some Points on the History of Pharmacy and Alchemy in Persia (from Antiquity to Rhazes)}

The early history of pharmacy is inseparable from the early medical history, but the separation between the diagnosis and cure of diseases, on one hand, and the manufacturing of medications, on the other hand, can be traced back for over 4000 years (9). History of pharmacy in Persia dates back to several centuries ago. The holy book of Avesta is the oldest document of pharmacy and medicine in ancient Persia (10). Pharmacist had been referred to as urvaro baešaza in Vandidad, a chapter of Avesta (11). Also, there is ample archeological evidence of pharmaceutical tools that belong to Persians in prehistoric and ancient times, showing the depth of pharmaceutical knowledge in Persia history (12). The Jundishapour School of Medicine, located in southeastern Iran, as the most important medical center in antiquity, was established during the Sassanid era (224-637
AD) $(13,14)$. One of the well-known pharmacists in this center was Shapur Sahl, who composed his Qarabadin-e- Kabir in $869 \mathrm{AD}$. (15). This book is the first pharmacopeia in history (16).

The history of Alchemy goes back to ancient Egypt, where the term "Khem" was applied to refer to fertility plains around the Nile River. After the conquest of Egypt by Alexander in $332 \mathrm{BC}$ and regarding the interest of Greek philosophers in Egyptian ways, Khemia, the Greek word for Egypt, was used, which is supposed to be the origin of the word alchemy (17). Jābir ibn Hayyan (circa 721-815), known Geber in European countries, was born in the city of Tus in the province of Khorasan Razavi in Iran. He is considered the father of early chemistry and one of the founders of modern pharmacy (18). In the history of science, Rhazes is known as one of the geniuses and experts in alchemy and pharmacy early in the 10th century. He was an expert in both chemistry and pharmacy and had great contributions to both fields (19).

\section{Rhazes (865-925 AD)}

Mohammad ibn Zakariya Razi, known in the western world as Rhazes or Rasis, was born in Ray, a city near the present Tehran, Iran. He was a great prolific writer, teacher, planner, philosopher, theologian, physician, chemist, and pharmacist in medieval medicine and also well-known as 'Persian Galen' (20). His earliest interests were art and music, and he wrote a music encyclopedia before the age of thirty. He was a pioneer of systematic practical chemistry in an equipped laboratory (9). He pursued the craft of goldsmith in his youth and was guided gradually to the art of alchemy. One of his innovations in alchemy was matter classification (Aghaghir) into three groups viz. 'Ajssad' (solids), 'Miah’ (liquids), and ‘Arvah' (Gases). He also subdivided naturally happening matters into animals, vegetables, and minerals (19). Also, he is credited for the discovery of sulfuric acid and ethanol, scientific classification of minerals, purification of oils, preparation of chemical compounds, including ammonium carbonate (Nushadur), mercury sulfide, and sodium and potassium sulfite, the first description of chemical reduction, production of colored glass, and synthesis of paints (21). According to al-Biruni, Rhazes stopped his studies in alchemy due to an eye disease brought for him by chemical experiments. After the age 30, Rhazes started to study philosophy and medicine under the supervision of Ali ibn Sahl Rabban al-Tabari. He was the physician in charge of the great hospital of Baghdad, who oversaw its rebuilding (20). He created a system of medical education that involved numerous consecutive rounds of students with various levels of 
experience (22). Also, he invented ward rounds for teaching his students at the bedside of patients. He published an excellent encyclopedia (Al-Hawi fi al-Tibb or Liber Continents) in 26 volumes, constituting Persian, Arabic, Syriac, Indian, and Greek resources improved by his own experiences and case studies, which was the first comprehensive review of medical knowledge. Three volumes of this book were applied as references in pharmacology in Western universities for many years (10). He wrote more than 200 manuscripts and treatises in pharmacy, chemistry, medicine, and other sciences (22).

\section{Rhazes' Books and Treatises on Pharmacy and Chemistry}

Rhazes' books and treatises in the fields of pharmacy and chemistry can be classified into three categories:

1) The books and treatises that contain some sections in the fields of pharmacy, such as Al-Mansouri fi al-Tibb (Figure 1) and Al-Hāwī fī al-Tibb (Table 1), 2) Books and treatises on pharmacy, such as Qarabadin (Table 2), and 3) Books and treatises on alchemy (kimia), such as Sirr al-Asrar (Figure 2) (Table 3).

According to Hassanali Sheibani in his introduction to the translation of Razi's 'al Madkhal al-Taalimi', out of 24 books and treatise of Rhazes on alchemy, only four books and two chapters are existing today (19). These four manuscripts are: 'al Madkhal al-Taalimi', 'Al shavahed va Naket al-Romuz, 'Al Asrar, and 'Sirr al-Asrar'.

\section{Discussion}

Rhazes is a unique figure in the history of science and has had great contributions to chemistry and pharmacy. Without a doubt, he and Geber are the pioneers of modern chemistry. Before them, alchemy was more a mysterious magical field than a branch of science. However, they, and in particular Rhazes, convert it to an important branch of science (26). Rhazes tried to clarify the facts of alchemy (chemistry) by publishing them in his books, manuscripts, and treatises. He, as a great researcher, was also involved in practical experiments and found and introduced many instruments, materials, and techniques in chemistry.

Pharmacy was a well-stablished medical field at the time of Rhazes, in both medications and services. There are many pharmaceutical books on single and compound medicines related to that era. There were also pharmacies (called Sharbat Khaneh) in hospitals and herbal shops (Attari) in the society, delivering pharmaceutical services to patients. Pharmacists (also named as Sheykh-e-Seydalani)

\begin{tabular}{|c|c|c|}
\hline Book name & Related Topics & Reference \\
\hline \multirow{3}{*}{$\begin{array}{l}\text { Qarabadin } \\
\text { (Pharmacopeia) }\end{array}$} & -62 chapters & \multirow{3}{*}{$(24)$} \\
\hline & $\begin{array}{l}\text {-Methods of preparing } \\
\text { compound drugs }\end{array}$ & \\
\hline & $\begin{array}{l}\text {-According to most of } \\
\text { physicians in the } \\
\text { Islamic era "The kind } \\
\text { of books" }\end{array}$ & \\
\hline $\begin{array}{l}\text { Al Saydalah } \\
\text { (Pharmacy) }\end{array}$ & $\begin{array}{l}\text {-No manuscript is } \\
\text { available }\end{array}$ & $(24)$ \\
\hline $\begin{array}{l}\text { Fi Dava al Moshel va } \\
\text { al Moqayye }\end{array}$ & $\begin{array}{l}\text {-About laxative and } \\
\text { vomiting drugs }\end{array}$ & $(24)$ \\
\hline Fi esqal al Adviye & $\begin{array}{l}\text {-Choosing the best } \\
\text { remedy }\end{array}$ & $(24)$ \\
\hline Abdal al Adviye & $\begin{array}{l}\text {-About replacement } \\
\text { medicines in different } \\
\text { conditions (for } \\
\text { example, when a } \\
\text { medicine is not } \\
\text { available, so you can } \\
\text { have another option) }\end{array}$ & $(24)$ \\
\hline \multirow{2}{*}{$\begin{array}{l}\text { Al Advie al Mojude be } \\
\text { Kole Makan (drugs } \\
\text { that exist } \\
\text { everywhere) }\end{array}$} & $\begin{array}{l}\text {-Physicians can treat } \\
\text { diseases with whatever } \\
\text { is found at homes and } \\
\text { kitchens }\end{array}$ & \multirow{2}{*}{$(24)$} \\
\hline & $\begin{array}{l}\text {-The aim of this book } \\
\text { was that physicians } \\
\text { could visit patients } \\
\text { anywhere and at any } \\
\text { situation, even when } \\
\text { there was no medicine } \\
\text { available. }\end{array}$ & \\
\hline $\begin{array}{l}\text { Maqale Fi Ettekhaz } \\
\text { Maa al Jobon (to } \\
\text { obtain whey protein) }\end{array}$ & $\begin{array}{l}\text {-About the properties } \\
\text { of the whey protein } \\
\text { and its way of } \\
\text { preparation }\end{array}$ & $(24)$ \\
\hline $\begin{array}{l}\text { Sekanjabin ha } \\
\text { (Oxymels) }\end{array}$ & $\begin{array}{l}\text {-About the effects of } \\
\text { various kinds of } \\
\text { sekanjabin and the } \\
\text { properties of each of } \\
\text { them }\end{array}$ & $(24)$ \\
\hline $\begin{array}{l}\text { Resale Daruhaye } \\
\text { Cheshmi (Treatise of } \\
\text { eye medicines) }\end{array}$ & $\begin{array}{l}\text {-About the methods of } \\
\text { preparing eye drugs } \\
\text { and how to use them }\end{array}$ & $(24)$ \\
\hline
\end{tabular}

managed these pharmacies (27). Pharmacy was an independent and separate field at the time, and some important figures like Biruni (973-1050 CE) and Masawaih (the 8 th century) were pharmacists, not physicians. Also, there were great polymaths who were both a physician and a pharmacist at the same time, like Avicenna (980-1032 CE), who greatly contributed to pharmacy development during this time. Nevertheless, Rhazes, as a pharmacist, had some privileges at his time, which are not found together in other scientists. He started his scientific career with chemistry and connected it to pharmacy. He had a great practical view and used his own research and experiences to develop pharmacy. Rhazes is known as a pioneer of 


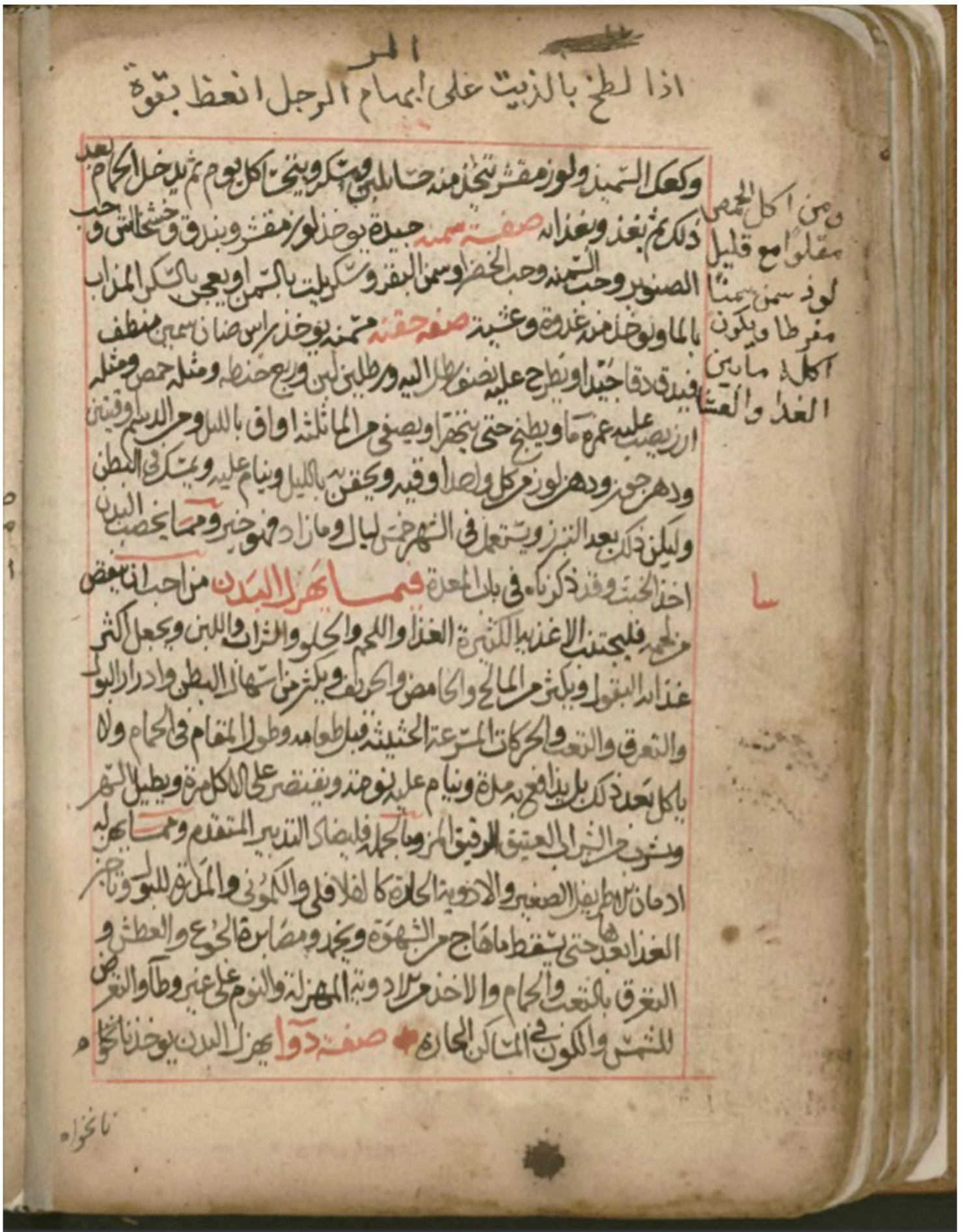

Figure 1. The page of the Book "Al-Mansouri fi al-Tibb" written by Rhazes (from Wikimedia Commons, the free media repository [Accessed 2021]. Available from: https://commons.wikimedia.org)

animal and human studies to evaluate the efficacy and safety of his medicines and medical approaches (28). Fur- 


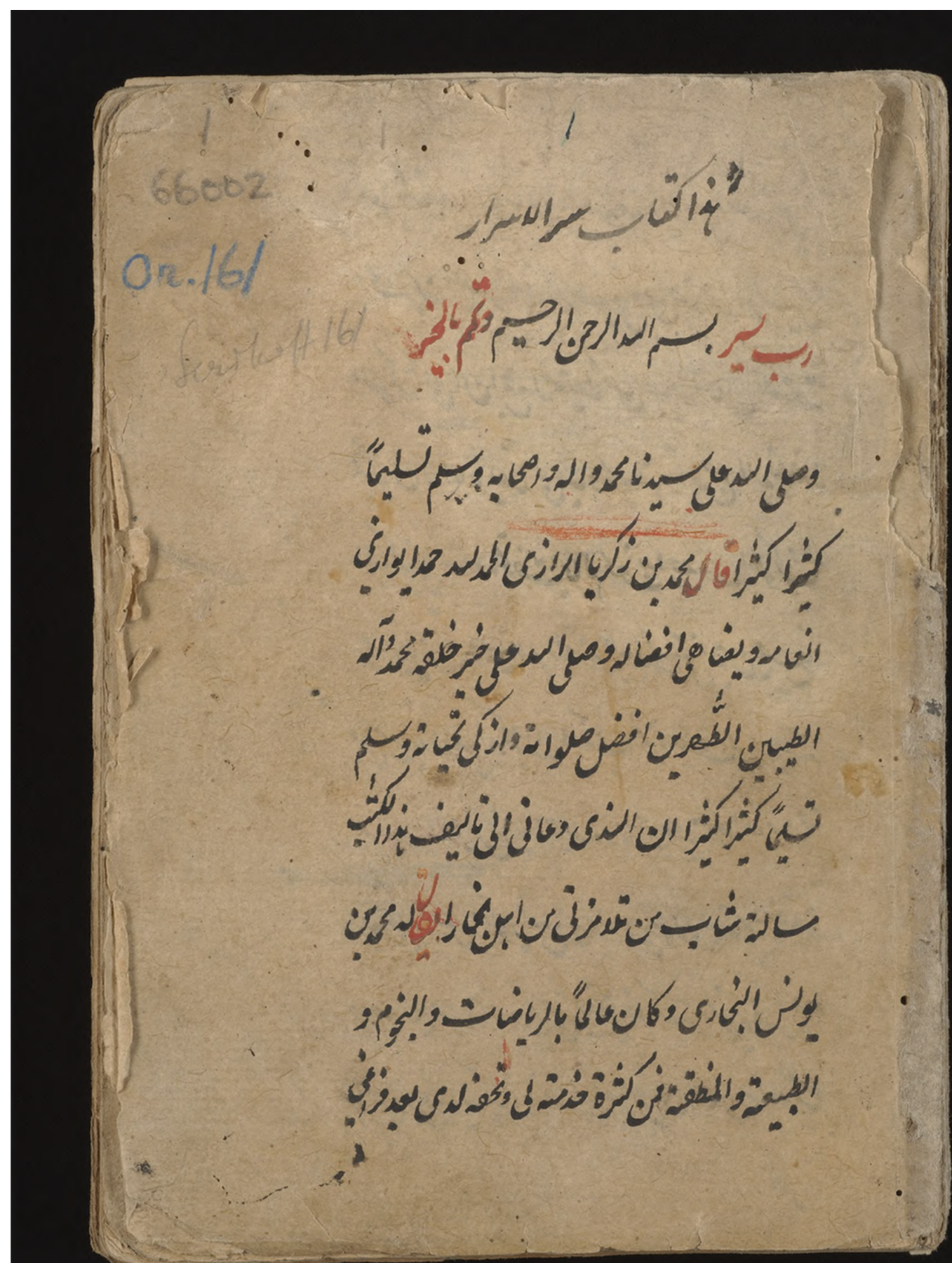

Figure 2. The page of the Book “Sirr al-Asrar (Secret of secrets) written by Rhazes (from World Digital Library. [Accessed 2020]. https://www.wdl.org/en/)

thermore, he had a critical perspective towards scientific issues and avoided accepting and copying predecessors' knowledge unless he would find them acceptable. This approach and scientific research view led him to write the 
book Doubts on Galen (Kitab al-Shukuk ala Jalinus) (29) and establish many discoveries in pharmacy. These features unified Rhazes in the Islamic Golden Age (9-13th century CE) as one of the most influential characters in the history of pharmacy and chemistry.

\section{Conclusion}

Rhazes was a unique Persian scholar who possessed many achievements in the fields of pharmacy and alchemy. This paper is only a general short description of his attempts and contributions to chemistry and pharmacy, and there is much more to be discussed about his work in further studies. The valuable manuscripts of Rhazes in pharmacy and chemistry shed light on a part of the rich ancient heritage of Persians and the great achievements of Persian scientists in the history of medicine.

\section{Footnotes}

Authors' Contribution: Study concept and design: A. Z. and E. A.; drafting the manuscript: S. S. and E. A.; critical revision of the manuscript for important intellectual content: A. Z and S. S. All authors read and approved the final manuscript.

Conflict of Interests: The authors declare that there is no conflict of interest.

Funding/Support: Not funding or support.

\section{References}

1. Bender GA. Great moments in pharmacy. Arizona Medical Center Library; 1974.

2. Schmitz R, Friedrich C, Müller-Jahncke W. Geschichte der Pharmazie. 2. Govi-Verlag; 1998.

3. Cowen DL, Helfand WH. Pharmacy: an illustrated history. 10. New York: Mosby; 1990.

4. Bullock C. PROCEEDINGS OF THE AMERICAN PHARMACEUTICAL ASSOCIATION-1859. Am J Pharm. 1859:0-1.

5. Anderson S. The historical context of pharmacy. Pharmacy practice. $\mathbf{2 1}$. London: Taylor \& Francis; 2001.

6. Rhazes. Al Asrar. Tehran: Tehran University Press; 1970.

7. Newman WR, Principe LM. Alchemy vs. chemistry: the etymological origins of a historiographic mistake. Early Sci Med.1998;3(1):32-65. doi: 10.1163/157338298x00022. [PubMed: 11620328].

8. Broumand B. The contribution of Iranian scientists to world civilization. Arch Iran Med. 2006;9(3):288-90. [PubMed: 16859071].
9. Anderson S. Making medicines: a brief history of pharmacy and pharmaceuticals. Pharmaceutical Press; 2005.

10. Farsam H. Brief History of pharmacy ethics in Iran. J Med Ethics Hist Med. 2009;2.

11. Zargaran A, Fazelzadeh A, Mohagheghzadeh A. Surgeons and surgery from ancient Persia (5,000 years of surgical history). World J Surg. 2013;37(8):2002-4. doi: 10.1007/s00268-013-2055-0. [PubMed: 23592059].

12. Zargaran A, Ahmadi SA, Daneshamouz S, Mohagheghzadeh A. Ancient Persian pharmaceutical vessels and tools in Iranian archaeological museums. Pharm Hist (Lond). 2012;42(4):68-71. [PubMed: 24620482].

13. Zargaran A. An introduction to medicine in Sassanid era. Tehran: Chogan; 2019.

14. Soleymani S, Zargaran A. A Historical Report on Preparing Sustained Release Dosage Forms for Addicts in Medieval Persia, 16th Century AD. Subst Use Misuse. 2018;53(10):1726-9. doi: 10.1080/10826084.2018.1432648. [PubMed: 29393724].

15. Elgood J. Gastroduodenal intussusception caused by a large leiomyoma of the stomach. Br J Surg. 1951;38(151):388-9. doi: 10.1002/bjs.18003815114. [PubMed: 14812115].

16. Zargaran A, Zarshenas MM. The History of Pharmacopeias in Iran (Persia): From Antiquity to Current Era. International Society for the History of Pharmacy; 2017.

17. Partington JR. A short history of chemistry. Courier Corporation; 1989.

18. Amr SS, Tbakhi A. Abu Bakr Muhammad Ibn Zakariya Al Razi (Rhazes): philosopher, physician and alchemist. Ann Saudi Med.2007;27(4):3057. doi: 10.5144/0256-4947.2007.305. [PubMed: 17684438]. [PubMed Central: PMC6074295].

19. Nayernouri T. Zakariya Razi: the Iranian physician and scholar. Arch Iran Med. 2008;11(2):229-34. [PubMed: 18298308].

20. Burland CA. The arts of the alchemists. Weidenfeld and Nicolson; 1967.

21. Moattar F, Moattar H. Ingenuities and Innovations of Rhazes in Alchemy. J Islam Iran Traditional Med. 2010;1(1):33-8.

22. Zarshenas MM, Mehdizadeh A, Zargaran A, Mohagheghzadeh A. Rhazes (865-925 AD). J Neurol. 2012;259(5):1001-2. doi: 10.1007/s00415011-6398-x. [PubMed: 22302275].

23. Modanlou HD. A tribute to Zakariya Razi ( 865 - 925 AD), an Iranian pioneer scholar. Arch Iran Med. 2008;11(6):673-7. [PubMed: 18976043].

24. Najmabadi M. Moallefat va Mossanafat Razi. Tehran: Tehran University; 1992.

25. Zarrintan S, Shahnaee A, Aslanabadi S. Rhazes (AD 865-925) and his early contributions to the field of pediatrics. Childs Nerv Syst. 2018;34(8):1435-8. doi: 10.1007/s00381-017-3493-z. [PubMed: 28681145].

26. Khoubnasabjafari M, Sadeghifar E, Khalili M, Vaez-Gharamaleki J Jouyban A. Contribution of Iranian chemists in research activities, on the occasion of the International Year of Chemistry. Revista Colombiana de Ciencias Químico-Farmacéuticas. 2011;40(2):240-60.

27. Golshani SA, Daneshfard B, Mosleh G, Salehi A. Drugs and Pharmacology in the Islamic Middle Era. Pharm Hist (Lond). 2015;45(3):64-9. [PubMed: 27352605]

28. Ghaffari F, Naseri M, Jafari Hajati R, Zargaran A. Rhazes, a pioneer in contribution to trials in medical practice. Acta Med Hist Adriat. 2017;15(2):261-70. doi: 10.31952/amha.15.2.4. [PubMed: 29402116].

29. Sjoha MM. Doubts on Galen: An English Translation of Rhazes' Forgotten Kitab al-Shukuk ala Jalinus. United States: Rhazes LLC; 2018. 
Table 1. Rhazes' Books and Treatises Containing a Number of Sections in the Field of Pharmacy

\begin{tabular}{|c|c|c|}
\hline Book name & Related topics & Reference \\
\hline \multirow{7}{*}{$\begin{array}{l}\text { Al-Hawi fi al-tibb (Al-Jam al-hazer le Sanaate } \\
\text { al-tibb) (Liber Continens) }\end{array}$} & -A comprehensive book on medicine & \multirow{7}{*}{$(17,23,24)$} \\
\hline & -26 volumes & \\
\hline & -Translated into Latin in 1297 A.D & \\
\hline & -Volumes of $2,3,4$, and 5 are related to pharmacy & \\
\hline & $\begin{array}{l}\text {-Volume 3: Compound drugs (Qarabadin or } \\
\text { pharmacopeia) }\end{array}$ & \\
\hline & $\begin{array}{l}\text {-Volume 4: Simple medicines and Tadabir } \\
\text { (processing) }\end{array}$ & \\
\hline & $\begin{array}{l}\text {-Volume 5: Preparation of remedies and their } \\
\text { properties (color, smell, and taste of medicines) }\end{array}$ & \\
\hline \multirow{6}{*}{$\begin{array}{l}\text { Al-Mansouri fi al-Tibb (Traite Mansouri or Liber } \\
\text { medicinalis Almansoris) }\end{array}$} & -Handbook for physicians & \multirow{6}{*}{$(23,24)$} \\
\hline & -One of his two most influential books & \\
\hline & $\begin{array}{l}\text {-Translated into Latin by Gherardo da Cremona in } \\
\text { the late 12th century }\end{array}$ & \\
\hline & -10 chapters & \\
\hline & -Third section is about foods and drugs & \\
\hline & $\begin{array}{l}\text {-Each volume was separately published in Europe in } \\
\text { the 15th century until the early Renaissance }\end{array}$ & \\
\hline \multirow{5}{*}{ Al Fosul fi al-Tibb or Al Murshid (The Guide) } & -29 chapters & \multirow{5}{*}{$(22)$} \\
\hline & -Chapters $6,13,14$, and 19 are in the field of pharmacy & \\
\hline & -Chapter 6: The strength of medicines and foods & \\
\hline & -Chapter 14: Vomiting and vomiting drug & \\
\hline & -Chapter 19: How to use combinations of medicines & \\
\hline \multirow{6}{*}{ Al Ghulenj (Colic) } & -18 Chapters & \multirow{6}{*}{$(24)$} \\
\hline & -Chapters $9,10,12$, and 13 are in the field of pharmacy & \\
\hline & -Chapter 9: Drugs used to treat colic & \\
\hline & -Chapter 10: Suppositories used to treat colic & \\
\hline & -Chapter 12: Sedative drugs used to relief colic pain & \\
\hline & -Chapter 13: Drugs for treating flatulence & \\
\hline \multirow[b]{6}{*}{ Ujae Mafasel (Pain of joints) } & $\begin{array}{l}\text {-According to some documents, this book involves } 22 \\
\text { sections, but the available manuscript has } 21 \text { sections }\end{array}$ & \multirow[b]{6}{*}{$(24)$} \\
\hline & $\begin{array}{l}\text {-Chapters } 7,8,9,10,11,12,13,14,16 \text {, and } 21 \text { are related to } \\
\text { pharmacy }\end{array}$ & \\
\hline & $\begin{array}{l}\text {-Chapter 7: Foods, drugs, and laxative agents used to } \\
\text { treat joint pain (Ujae Mafasel har) }\end{array}$ & \\
\hline & $\begin{array}{l}\text {-Chapter 8: Laxative drugs used to treat the joint pain } \\
\text { caused by phlegm (Balgham) }\end{array}$ & \\
\hline & $\begin{array}{l}\text {-Chapter 9: Laxative drugs used for the excretion of } \\
\text { black bile (Soda) }\end{array}$ & \\
\hline & $\begin{array}{l}\text {-Chapter 10: Laxative drugs to exert phlegm and bile } \\
\text { (Safra). }\end{array}$ & \\
\hline
\end{tabular}




\begin{tabular}{|c|c|c|}
\hline & $\begin{array}{l}\text {-Chapter 11: Sedative drugs used to alleviate joint } \\
\text { ache }\end{array}$ & \\
\hline & -Chapter 12: Enema drugs used for swollen hip joint & \\
\hline & $\begin{array}{l}\text {-Chapter 13: Sedative plaster and emulsion used for } \\
\text { acute joint ache }\end{array}$ & \\
\hline & $\begin{array}{l}\text {-Chapter 14: Sedative plaster beneficial for headache } \\
\text { and joint pain }\end{array}$ & \\
\hline & -Chapter 16: Plaster to warm joint & \\
\hline & -Chapter 21: All the drugs used to alleviate joint pain & \\
\hline \multirow{6}{*}{ Kitab al Bah } & -13 Chapters & \multirow{6}{*}{ (24) } \\
\hline & -Chapters $7,8,9$, and 10 are related to pharmacy & \\
\hline & $\begin{array}{l}\text {-Chapter 7: Simple foods and syrups for enhancing } \\
\text { semen }\end{array}$ & \\
\hline & $\begin{array}{l}\text {-Chapter 8: Compound remedies useful for } \\
\text { production of semen }\end{array}$ & \\
\hline & $\begin{array}{l}\text {-Chapter 9: Suppositories and drugs that increase } \\
\text { libido }\end{array}$ & \\
\hline & -Chapter 10: Topical drugs used for enhancing libido & \\
\hline \multirow[b]{2}{*}{ Tibb al Moluki (Medicine for Kings) } & -Brief and meaningful & \multirow[b]{2}{*}{ (24) } \\
\hline & -Topics are about food and drug therapy for kings & \\
\hline \multirow{4}{*}{ Man la Yahduruhu al-Tabib or Tibb al Fuqara } & -About available drugs & \multirow{4}{*}{$(24,25)$} \\
\hline & -36 chapters & \\
\hline & -A medical advisor for the general public & \\
\hline & $\begin{array}{l}\text {-The book is dedicated to the poor, travelers, and } \\
\text { ordinary citizens who could refer to it for treating } \\
\text { common ailments when a doctor was not available. }\end{array}$ & \\
\hline Fi Alaje Ain bel Hadid & -Eye diseases and their medication & $(24)$ \\
\hline \multirow{2}{*}{$\begin{array}{l}\text { Fi al Adviyah al Ain va Alajeha (eye drugs and } \\
\text { treatments) }\end{array}$} & -Eye diseases and their medications & \multirow{2}{*}{ (24) } \\
\hline & $\begin{array}{l}\text {-For example, two drugs to prevent the ocular } \\
\text { complications of smallpox and measles }\end{array}$ & \\
\hline Mofid al Khas & -Pharmacy topics, along with others & (24) \\
\hline
\end{tabular}


Table 3. Rhazes' Book and Treatises on Alchemy (kimia)

\begin{tabular}{|c|c|c|}
\hline Book name & Related topics & Reference \\
\hline \multirow{2}{*}{$\begin{array}{l}\text { Al Asrar (Book of secrets, known in the Latinate } \\
\text { world as Liber Secretorum) }\end{array}$} & $\begin{array}{l}\text {-Popular in Europe, having significant impacts on } \\
\text { European chemists }\end{array}$ & \multirow{2}{*}{$(6,19)$} \\
\hline & $\begin{array}{l}\text { Three chapters: recognizing materials, identifying } \\
\text { tools, identifying procedures }\end{array}$ & \\
\hline \multirow{5}{*}{ Sirr al-Asrar (Secret of secrets) } & $\begin{array}{l}\text {-There is a small difference between Al Asrar and Sirr } \\
\text { al-Asrar in various manuscripts, and it seems that } \\
\text { these two books are the same. }\end{array}$ & \multirow{5}{*}{$(19,24)$} \\
\hline & -Three chapters & \\
\hline & $\begin{array}{l}\text {-Chapter 1: Fī ma'rifat al-aqāqīir (On simples), } \\
\text { describes raw materials in alchemy }\end{array}$ & \\
\hline & $\begin{array}{l}\text {-Chapter 2: Fī ma'rifat al-'ālāt (On instruments), } \\
\text { provides short descriptions on the experimental } \\
\text { apparatus necessary for alchemical work, } \\
\text { including al-kur (laboratory } \\
\text { furnaces), al-'inbiq (alembics), al-qadah (bowls), } \\
\text { and al-fihr (pestles). }\end{array}$ & \\
\hline & $\begin{array}{l}\text {-Chapter 3, Fī ma'rifat al-tadābīr (On methods), } \\
\text { makes up the major part of the book and discusses } \\
\text { many detailed procedures for the chemical } \\
\text { manipulation of } \\
\text { zarnikh (arsenic), Nushadur, kibrit (Sulphur), and } \\
\text { other materials. }\end{array}$ & \\
\hline \multirow[t]{2}{*}{ Al Madkhal at Taalimi (Al-Muhamal al-Salimini's) } & -A comprehensive course on chemistry & \multirow{2}{*}{$(23,24)$} \\
\hline & -A guide for educating the industry of kimia & \\
\hline Al Shavahed va Nokat al-Romuz & - Its second name is Al shavahed va Nokat al-Romuz. & $(23,24)$ \\
\hline Fi an Sanaat al Kimia (the industry of kimia) & $\begin{array}{l}\text {-Rhazes believed that alchemy science was } \\
\text { achievable. }\end{array}$ & $(24)$ \\
\hline Fi Sirr al Sina'at & - & $(24)$ \\
\hline \multirow{2}{*}{ Al Abyat } & -Its second name is Esbat al-Sina'at or Al-esbat. & \multirow{2}{*}{$(24)$} \\
\hline & $\begin{array}{l}\text {-There is no complete manuscript from this book } \\
\text { available. }\end{array}$ & \\
\hline Al-Tadbir & - & $(24)$ \\
\hline Al-Mohabbat & $\begin{array}{l}\text { In some documents, it has been named Mahan al } \\
\text { Zahab va al Fezzah }\end{array}$ & $(24)$ \\
\hline Sharaf al-Sanae va Fazleha (Honor of industry) & & $(24)$ \\
\hline Al-Tartib & -Its second name is Al-tartib va hova al-Rayehe. & $(24)$ \\
\hline Al-Hil & -Its other name is "Ser al-Hokama". & $(24)$ \\
\hline Al-Rad Ala alkendi & $\begin{array}{l}\text {-Rhazes has written here about the rejection of } \\
\text { Kendy idea (Kendy has rejected alchemy). }\end{array}$ & $(24)$ \\
\hline Al-Rad Ala Mohammad ibn Lais & $\begin{array}{l}\text {-Rhazes has rejected here the ideas of Mohammad } \\
\text { ibn Lais, who rejected alchemy. }\end{array}$ & $(24)$ \\
\hline Al-Khase & $\begin{array}{l}\text {-This book was registered by Ibn Nadim in the list of } \\
\text { Rhazes' alchemic books, but it may mean the book } \\
\text { Mufid al-Khas or the book Khavas al-Ashiya. }\end{array}$ & $(24)$ \\
\hline Al-Tabvib & $\begin{array}{l}\text {-This book was registered by Ibn Nadim in the list of } \\
\text { Rhazes' alchemic books. }\end{array}$ & $(24)$ \\
\hline Resael al-Mulook & $\begin{array}{l}\text {-This book has was by Ibn Nadim in the list of Rhazes' } \\
\text { alchemic books. }\end{array}$ & $(24)$ \\
\hline
\end{tabular}




\begin{tabular}{l|l|l} 
& & \\
\hline \multirow{2}{*}{ Al Hajar e al-asfar } & -Probably it is the same book known as “Al-Hajar". & \multirow{2}{*}{$(24)$} \\
\cline { 2 - 3 } & $\begin{array}{l}\text {-This book was registered by Ibn Nadim in the list of } \\
\text { Rhazes' alchemic books. }\end{array}$ & $(24)$ \\
\hline Al-Ahjar (the stones) & - & $(24)$ \\
\hline Al Exir & -10 chapters & $(24)$ \\
\hline $\begin{array}{l}\text { Fi mehnat al-Zahab va al-Zahab va al-Mizan } \\
\text { al-Tabie }\end{array}$ & $\begin{array}{l}\text {-Probably it is the same book known as “Mahan } \\
\text { al-Zahab va al-Fezzah". }\end{array}$ \\
\hline
\end{tabular}

